\title{
Repurposing of antibiotics for clinical management of COVID-19: a narrative review
}

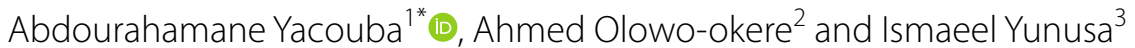

\begin{abstract}
Background: Drug repurposing otherwise known as drug repositioning or drug re-profiling is a time-tested approach in drug discovery through which new medical uses are being established for already known drugs. Antibiotics are among the pharmacological agents being investigated for potential anti-SARS-COV-2 activities. The antibiotics are used either to resolve bacterial infections co-existing with COVID-19 infections or exploitation of their potential antiviral activities. Herein, we aimed to review the various antibiotics that have been repositioned for the management of COVID-19.

Methods: This literature review was conducted from a methodical search on PubMed and Web of Science regarding antibiotics used in patients with COVID-19 up to July 5, 2020.

Results: Macrolide and specifically azithromycin is the most common antibiotic used in the clinical management of COVID-19. The other antibiotics used in COVID-19 includes teicoplanin, clarithromycin, doxycycline, tetracyclines, levofloxacin, moxifloxacin, ciprofloxacin, and cefuroxime. In patients with COVID-19, antibiotics are used for their immunemodulating, anti-inflammatory, and antiviral properties. The precise antiviral mechanism of most of these antibiotics has not been determined. Moreover, the use of some of these antibiotics against SARS-CoV-2 infection remains highly controversial and not widely accepted.
\end{abstract}

Conclusion: The heavy use of antibiotics during the COVID-19 pandemic would likely worsen antibiotic resistance crisis. Consequently, antibiotic stewardship should be strengthened in order to prevent the impacts of COVID-19 on the antibiotic resistance crisis.

Keywords: COVID-19, SARS-CoV-2, Drug repurposing, Antibiotics

\section{Introduction}

In December 2019, a pneumonia like disease of unknown cause emerged in Wuhan, an emerging business hub located in the Hubei province of China [1]. The disease was caused by a highly transmissible, hitherto undescribed beta-coronavirus, the SARS-coronavirus-2 (SARS-CoV-2) $[2,3]$. The disease rapidly spread globally prompting the World Health Organisation (WHO) to declare it a global pandemic in March, 2020 [4]. As

\footnotetext{
*Correspondence: abdourahamanaeyacouba@yahoo.fr

${ }^{1}$ Faculté des Sciences de la Santé, Université Abdou Moumouni, P.M.B. 10896, Niamey, Niger
}

Full list of author information is available at the end of the article of 24th November 2020, 59,175,309 laboratory-confirmed COVID-19 cases were reported worldwide, with 1,396,403 deaths [5].

The rising biological, clinical, and socio-economic impacts of this COVID-19 diseases underscore the urgent need for effective resolution of this crisis [6, 7]. Currently, there is no specific vaccine or an approved antiviral for its effective treatment, several strategies are however being explored [3]. Drug repurposing offers a quick and costeffective strategy to achieve this [8]. Drug repurposing otherwise known as drug repositioning or drug re-profiling is a time-tested approach in drug discovery through which new medical uses are being established for already known drugs, including approved, discontinued, shelved 
and experimental drugs [8]. This approach offers considerable advantage over the search for novel molecules. The advantages of drug repurposing have been summarised in a published review article on drug repurposing [8]. This approach has been successful used to brought back several drugs to the market [9]. Zidovudine for example, a well-known antiviral drug active against human immunodeficiency virus (HIV) has been shown to demonstrate in-vitro activity against colistin-resistant and carbapenem-resistant isolates [10]. Similarly, some anti-cancer drugs have been successfully repurposed for treatment of resistant bacterial infections [11]. Other successful examples abound in the literature.

Currently, various pharmacological agents are being investigated for potential use in the clinical management of coronavirus diseases [12-15]. The inclusion of antibiotics in the clinical management of COVID-19 is aimed at achieving either the resolution of any bacterial infections co-existing with the COVID-19 infections or exploitation of its potential antiviral activities. Bacterial co-infection is common feature in Covid-19 diseases [16]. As much as 94.2\% patients with confirmed cases of COVID-19 diseases in China have been found to be co-infected with one or more other pathogens [17]. In another study, $51.35 \%$ of paediatric patients with COVID-19 diseases were also co-infected with other pathogens [18]. The prominent use of antibiotics in the clinical management of COVID-19 diseases is therefore not out of place. In this article, we aimed to review the various antibiotics that have been repositioned for clinical management of COVID-19 diseases. This review focuses on the current state of knowledge regarding the repurposing of antibiotics in terms of their modes of action, antiviral efficacy, and the advances to-date in their development as antiviral agents for clinical use.

\section{Methods}

\section{Literature search strategy}

A methodical search of PubMed and Web of Science was conducted to identify articles published up till July 5 , 2020 that involved studies on repurposing of antibiotics for clinical management of COVID-19 diseases.

The following 'Medical Subject Headings' (MeSH) terms and text words were used to search articles in PubMed: (Drug Repurposing or Drug Re-profiling or Drug re-positioning) AND (Antibiotics.mp.) OR (Anti-Bacterial Agents) OR (Antimicrobial agents.mp. or Anti-Infective Agents) AND (Coronavirus disease) OR (COVID 19.mp.) OR (SARS-coronavirus-2 diseases.mp.) The following keywords were used to search articles in Web of Science: ("Drug Repurposing" or "Drug Re-profiling" or "Drug re-positioning") AND ("Antibiotics" OR "AntiBacterial Agents") AND ("COVID-19" OR "corona virus disease" OR "SARS-coronavirus disease"). In addition, Google Scholar was also searched for articles with the appropriate keywords. References of identified were also searched.

\section{Results}

Collected data related to the use of antibiotics in COVID19 (up to July 5, 2020) are summarised in Table 1. Figure 1 shows the scheme of potential targets of repurposed antibiotics against SARS-CoV-2.

\section{Macrolides (azithromycin and clarithromycin)}

Macrolides are a class of broad-spectrum antibiotics of large molecular size, including among others erythromycin, clarithromycin, and azithromycin [19]. Macrolides have generally a good tolerability profile [19]. Drugs in this class are used primarily to treat both local and systemic infections, including infections of the skin, eyes, respiratory tract, gastrointestinal tract, and genital tract [19]. In addition to their antibacterial activities, numerous macrolides antibiotics have been shown to possess considerable antiviral activities [20-24].

Among the antibiotics used against COVID-19, azithromycin is the most frequently used. Azithromycin is a broad-spectrum, macrolide antibiotic [25]. It has aa long half-life and excellent tissue penetration [25]. Numerous studies have previously reported the antiviral activity of azithromycin against Ebola virus and Zika virus [20-22]. In the management of COVID-19, azithromycin is used alone or in combination with hydroxychloroquine [26-29]. It is recommended for use at the early stage of the disease especially before the on-set of complications [30, 31]. Studies have however shown that the efficacy of azithromycin alone or in combination with hydroxychloroquine in COVID-19 remain highly controversial and not widely accepted $[28,32]$.

The mechanism through which azithromycin exerts its antiviral activity is still unknown. Nevertheless, numerous mechanisms have been proposed. It has been proposed that azithromycin may inhibit acidification of endosome during viral replication and infection (Table 1) [33]. As a weak base, azithromycin accumulates in endosomal vesicles, increasing the $\mathrm{pH}$ level. Endosomal acidification and cleavage processes are required for the viral replication and infection. Another possible target for azithromycin is the un-coating step during viral infection [34]. This step in the virus life cycle also requires acidic environment. Furthermore, based on their anti-inflammatory and immunomodulatory effects, azithromycin has been proposed as option for patients with virus infections and inflammatory basis [34]. Azithromycin reduces the production of pro-inflammatory cytokines such as interleukins-8 (IL-8), IL-6, tumor necrotic factor alpha 
Table 1 Collected data related to the use of antibiotics in COVID-19 (up to July 5, 2020)

\begin{tabular}{|c|c|c|c|c|}
\hline Authors name + reference & Antibiotics & Types of study & $\begin{array}{l}\text { Potential viral targets and/ } \\
\text { or other properties }\end{array}$ & IC50 inhibition or posology \\
\hline Pani et al. [82] & Azithromycin & Review & $\begin{array}{l}\text { Anti-inflammatory and } \\
\text { immunomodulatory } \\
\text { effects }\end{array}$ & Not indicated \\
\hline Choudhary et al. [83] & Azithromycin & Review & Membrane fusion inhibition & Not indicated \\
\hline Gautret et al. [26] & Azithromycin & Non-randomized clinical trial & Membrane fusion inhibition & $\begin{array}{l}500 \mathrm{mg} \text { on the first day then } \\
250 \mathrm{mg} \text { /day for } 5 \text { more } \\
\text { days }\end{array}$ \\
\hline Andreani et al. [32] & Azithromycin & In vitro & Membrane fusion inhibition & 10 and $5 \mu \mathrm{M}$ \\
\hline Touret et al. [84] & Azithromycin, levofloxacin & In vitro & $\begin{array}{l}\text { Membrane fusion inhibition } \\
\text { and replication inhibition }\end{array}$ & Not indicated \\
\hline Ceccarelli et al. [42] & Teicoplanin & Letter to the editor & $\begin{array}{l}\text { Interaction between viral } \\
\text { spike protein and ACE2 } \\
\text { receptors inhibition }\end{array}$ & $6 \mathrm{mg} / \mathrm{kg}$ every $24 \mathrm{~h}$ \\
\hline Baron et al. [41] & Teicoplanin & Editorial & $\begin{array}{l}\text { Interaction between viral } \\
\text { spike protein and ACE2 } \\
\text { receptors inhibition }\end{array}$ & Not indicated \\
\hline Zhang et al. [43] & Teicoplanin & Original article & $\begin{array}{l}\text { Interaction between viral } \\
\text { spike protein and ACE2 } \\
\text { receptors inhibition }\end{array}$ & $1.66 \mu \mathrm{M}$ \\
\hline Sathyamoorthy et al. [85] & Teicoplanin & Letter to the editor & $\begin{array}{l}\text { Interaction between viral } \\
\text { spike protein and ACE2 } \\
\text { receptors inhibition }\end{array}$ & Not indicated \\
\hline He and Garmire [86] & $\begin{array}{l}\text { COL-3 (a chemically modi- } \\
\text { fied tetracycline) }\end{array}$ & Computational study & $\begin{array}{l}\text { Interaction between viral } \\
\text { spike protein and ACE2 } \\
\text { receptors inhibition }\end{array}$ & Not indicated \\
\hline Sodhi and Etminan [87] & Tetracyclines & Letter to the editor & $\begin{array}{l}\text { Zinc-chelating and anti- } \\
\text { inflammatory effects }\end{array}$ & Not indicated \\
\hline Wang [58] & Eravacycline, streptomycin & Computational study & Replication inhibition & Not indicated \\
\hline Conforti et al. [88] & Doxycycline & Letter to the editor & Anti-inflammatory effect & Not indicated \\
\hline Farouk and Salman [89] & Doxycycline & Letter to the editor & Anti-inflammatory effect & Not indicated \\
\hline Malek et al. [90] & Doxycycline & Editorial & Anti-inflammatory effect & Not indicated \\
\hline Szolnoky [91] & Doxycycline & Letter to the editor & Anti-inflammatory effect & Not indicated \\
\hline Sargiacomo et al. [52] & Doxycycline, azithromycine & Research perspective & $\begin{array}{l}\text { Protein synthesis, viral repli- } \\
\text { cation inhibition }\end{array}$ & Not indicated \\
\hline Bonzano et al. [92] & Doxycycline & Opinion & $\begin{array}{l}\text { Protein synthesis, viral } \\
\text { replication inhibition, and } \\
\text { immunomodulatory effect }\end{array}$ & Not indicated \\
\hline $\begin{array}{l}\text { Karampela and Dalamaga } \\
\text { [64] }\end{array}$ & Levofloxacin, moxifloxacin & Opinion & Immunomodulatory effect & Not indicated \\
\hline Marciniec et al. [65] & Ciprofloxacin, moxifloxacin & In silico study & Viral replication inhibition & Not indicated \\
\hline Durojaiye et al. [81] & Cefuroxime & In silico study & $\begin{array}{l}\text { Interaction between viral } \\
\text { spike protein and ACE2 } \\
\text { receptors and viral replica- } \\
\text { tion inhibition }\end{array}$ & Not indicated \\
\hline Chalichem et al. [73] & Aminoglycosides & & Membrane fusion inhibition & Not indicated \\
\hline
\end{tabular}

(TNF- $\alpha$ ), matrix metalloproteinases (MMPs) [35]. It also reduces oxidative stress, and modulate $\mathrm{T}$-helper functions [35].

Because of the comparable mode of action of azithromycin and clarithromycin, clarithromycin was the second macrolide antibiotic proposed for the treatment of COVID-19 patients [23, 24]. However, subtle differences exist in the pharmacodynamics, pharmacokinetics, drug interaction, and safety of the two drugs [36]. Studies have demonstrated the antiviral properties of clarithromycin in seasonal influenza virus infection [23, 24]. A recent study has shown that clarithromycin in combination with chloroquine significantly improved clinical condition of a patient with SARS-coronavirus-2 infections and the patient tested negative by rRT-PCR test in less than 14 days [37]. 


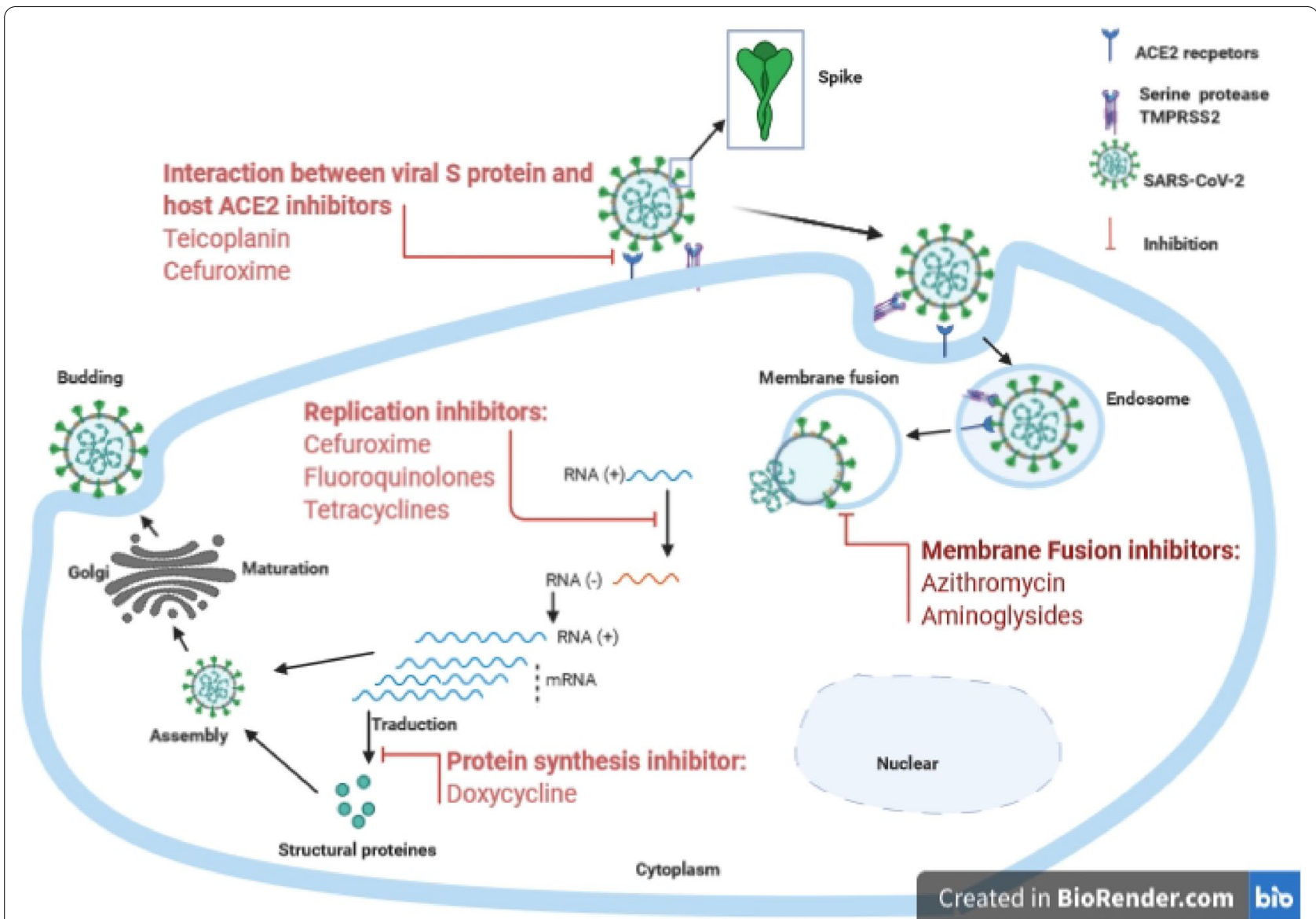

Fig. 1 Scheme of potential targets of repurposed antibiotics against SARS-CoV-2

Similar to azithromycin, the exact antiviral mechanism of clarithromycin has also not been determined. It has however been suggested that clarithromycin "suppresses infection-related inflammation and reduces vascular hyper-permeability by suppressing the induction of monocyte chemoattractant protein-1 (MCP-1) and matrix metalloproteinases-9 (MMP-9)" [24].

\section{Glycopeptide (teicoplanin)}

Glycopeptides are a group of large molecular weight antibiotics that inhibit transglycosylation and transpeptidation, the later stage of bacterial cell-wall peptidoglycan biosynthesis [38]. This class includes vancomycin and teicoplanin [38]. They are the last-line antibiotic for treatment of severe infections caused by multidrug resistant Gram-positive pathogens, particularly methicillin-resistant Staphylococcus aureus (MRSA) and Enterococci. In addition to their antibacterial properties, glycopeptides and specifically teicoplanin have been shown to exhibit significant antiviral activities [39]. Previously, the antiviral activity of teicoplanin against Ebola virus, SARS$\mathrm{CoV}$, and MERS-CoV has been established. This has been suggested to be due to inhibition of entry of the viral particles into the cells $[39,40]$.

The potential activity of teicoplanin against SARSCoV-2 was first postulated by Baron et al. [41]. In another study, teicoplanin at a dose of $6 \mathrm{mg} / \mathrm{kg}$ every $24 \mathrm{~h}$ for 10 days was found to be effective and safe for the treatment of 2019-nCoV virus infection [42].

The precise anti-viral mechanism of teicoplanin has also not been determined. It has however been suggested that teicoplanin potently block the entry of SARS-CoV-2 through the inhibition of the enzymatic activity of cathepsin L [43]. Based on this, the authors recommended the use of teicoplanin in both prophylaxis and therapeutic management of patients with SARS-CoV-2 infection [43].

\section{Tetracyclines (doxycycline, eravacycline)}

Tetracyclines are broad spectrum bacteriostatic and lipophilic antibiotics with high tissue penetration in the lungs [44]. These drugs exerts their activity by binding to bacterial ribosomes and interact with conserved region of bacterial 16S ribosomal RNA (rRNA) leading to inhibition 
of bacterial protein synthesis, by preventing the association of aminoacyl-tRNA with the bacterial ribosome [44]. Tetracyclines antibiotics have high activity against Grampositive and -negative bacteria, spirochetes, obligate intracellular bacteria, as well as protozoan parasites [44]. In addition to this, tetracyclines have a number of nonantibiotic effects including substantial antiviral activities [45-47].

The antiviral activity of doxycycline was first described by Sturtz [47]. This has been further confirmed by other researchers [45, 46, 48, 49]. The antiviral effects of doxycycline may be due to up-regulation of zinc finger antiviral protein (ZAP), preventing the accumulation of viral RNA in the cytoplasm $[50,51]$. Doxycycline as a senolytic drug could inhibit protein synthesis, senescenceassociated secretory phenotype, viral replication, and prevent lung fibrosis [52]. Doxycycline may also exert anti-inflammatory effect in patients with viral infection by inhibiting pro-inflammatory cytokines, including IL-6 and tumor necrosis factor (TNF)- $\alpha$ [53]. The commonest morbid complication of SARS-CoV2- induced pneumonia are the hyper-inflammation and cytokine storm [54, 55]. Moreover, a computational model revealed that doxycycline is a potential drug candidate for SARS-CoV-2, by inhibiting the SARS-CoV-2 main proteinase (Mpro), also known as 3-chymotrypsin like protease (3CLpro) [56]. This 3CLpro plays important roles in proteolytic processing of viral polyproteins, essentially in the replication of RNA viruses, including SARS coronavirus [57]. In another computational study, eravacycline, a synthetic halogenated tetracycline class antibiotic was found as the "second-best repurposed drug candidate" for SARSCoV-2 main protease [58].

\section{Fluoroquinolones (ciprofloxacin, moxifloxacin and levofloxacin)}

Fluoroquinolones are a class of broad-spectrum synthetic antibiotics. Fluoroquinolones inhibited the activities of prokaryotic DNA gyrase-topoisomerase II and topoisomerase IV, which are essential for DNA replication and transcription [59]. This class of antibiotics has high activity against Gram-negative and Gram-positive bacteria, mycobacteria, and anaerobes bacteria [59]. In addition to their antibacterial effects, the potential antiviral property of fluoroquinolones against both DNA and RNA viruses is also well documented [60-63].

Studies have demonstrated the potential action of fluoroquinolones for the treatment of SARS-CoV-2 associated pneumonia and called for randomized clinical trials of respiratory fluoroquinolones such as ciprofloxacin, moxifloxacin and levofloxacin [64, 65]. Interestingly, these drugs were also recommended in the treatment of community-acquired pneumonia in COVID-19 patients [66].

As a chemical derivative of quinoline, the prodrome of chloroquine, the antimalarial drug which has been proven effective in COVID-19 patients [12, 26], fluoroquinolones may exert antiviral activity in the treatment of SARS-CoV-2 infection. Ciprofloxacin and moxifloxacin may bind to SARS-CoV-2 3CLpro which is involved in the inhibition of SARS-CoV-2 replication [65]. Furthermore, fluoroquinolones also have immune-modulatory activity leading to attenuation of cytokines response, essential for the infamous cytokines storm syndrome [67, 68].

\section{Aminoglycosides}

Aminoglycosides are one of the oldest classes of antibiotics. Aminoglycosides exert antibacterial activity by binding specifically to the aminoacyl site of $16 \mathrm{~S}$ ribosomal RNA (rRNA) within the $30 \mathrm{~S}$ ribosomal subunit and interfere with protein synthesis [69]. Aminoglycosides have relatively high frequency of nephrotoxicity and ototoxicity [70]. Gentamycin, tobramycin, and amikacin are the most prescribed aminoglycosides in clinical practice [70]. These bactericidal antibiotics have high activity against Gram-positive and Gram-negative bacteria and mycobacteria [70]. Additionally, aminoglycosides have a number of proven non-antibacterial therapeutic uses including antiviral properties [71, 72].

According to Chalichem et al., the effectiveness of aminoglycosides against SARS-CoV-2 may be due to production of retrocyclins, a functional peptide produced from human theta defensins, which inhibits cellular fusion and aggregation of SARS-CoV-2 [73]. Humans defensins exert a well-documented antiviral activity against both enveloped and non-enveloped viruses [74-78].

Unfortunately, the adverse impact of SARS-CoV-2 infection on olfaction [79] counteract with the wellknown ototoxicity associated with the use of aminoglycosides. Consequently, the clinical use of aminoglycosides in the management of patients with SARS-CoV-2 infection was discouraged [79].

\section{Cephalosporins (cefuroxime)}

Cephalosporins in combination with beta-lactamase inhibitors are commonly used in elderly patients with community-acquired pneumonia [80]. Cefuroxime is a second-generation cephalosporin antibiotic with broad spectrum activity. It generally has good tolerability and safety profiles and it is used to treat respiratory and genitourinary tract infections, and Lyme disease. In a recent review, the authors have shown in-silico evidence of the potential action of cefuroxime against three SARS-CoV-2 proteins, including main protease, 
RNA-dependent RNA polymerase, and angiotensinconverting enzyme 2 (ACE2)-Spike complex [81]. However, no in-vitro or human clinical trial has been conducted to establish the proprieties of this finding.

\section{Conclusion}

Antibiotic repurposing is one of the therapeutic strategies being employed in the clinical management of COVID-19. This is aimed at either the resolution of any bacterial infections co-existing with the COVID19 infections or exploitation of its potential antiviral properties. Though some of these antibiotics have shown promising results, their use remains highly controversial and not widely accepted. Moreover, the precise antiviral mechanism of most of these antibiotics has not yet been determined. Considering the positive association between heavy antibiotic use and worsening of antibiotic resistance crisis, efforts should be made to strengthen antibiotic stewardship at both national and sub-national levels so as to reduce the long and short impact of antibiotic use in COVID-19 on the antibiotic resistance crisis. Also, data are needed to increase the body of evidence and the clinicians' confidence in the use of antibiotics for COVID-19 diseases.

\section{Acknowledgements}

Not applicable.

\section{Authors' contributions}

$A Y$ and $A O$ conceived and designed the study. $A Y$ and $A O$ drafted the manuscript. The manuscript was critically reviewed by IY. All authors read and approved the final version of the manuscript.

\section{Funding}

Not applicable.

\section{Availability of data and materials}

All relevant data are available within the paper. https://doi.org/10.6084/m9 figshare.12690077.v1.

\section{Declarations}

Ethics approval and consent to participate

Not applicable.

\section{Consent for publication}

Not applicable.

\section{Competing interests}

No competing interests were disclosed.

\footnotetext{
Author details

${ }^{1}$ Faculté des Sciences de la Santé, Université Abdou Moumouni, P.M.B. 10896, Niamey, Niger. ${ }^{2}$ Faculty of Pharmaceutical Sciences, Usmanu Danfodiyo University, P.M.B. 2346, Sokoto, Nigeria. ${ }^{3}$ Department of Clinical Pharmacy and Outcomes Sciences, University of South Carolina College of Pharmacy, Columbia, SC, USA.
}

Received: 19 September 2020 Accepted: 11 May 2021 Published online: 21 May 2021

\section{References}

1. Zhu N, Zhang D, Wang W, Li X, Bo Yang JS, Ma X, et al. A novel coronavirus from patients with pneumonia in China, 2019. N Engl J Med. 2020;382:727-33.

2. Cheng ZJ, Shan J. 2019 Novel coronavirus: where we are and what we know. Infection. 2020;48:155-63.

3. Singhal T. A review of coronavirus disease-2019 (COVID-19). Indian J Pediatr. 2020;87:281-6.

4. World Health Organization (WHO). WHO Director-General's opening remarks at the media briefing on COVID-19-11 March 2020. WHO. 2020. https://www.who.int/director-general/speeches/detail/. Accessed 9 Sept 2020

5. University JH. COVID-19 Map. Johns Hopkins Coronavirus Resource Center. 2020. https://coronavirus.jhu.edu/map.html. Accessed 9 Sept 2020.

6. Nicola M, Alsafi Z, Sohrabi C, Kerwan A, Al-jabir A. The socio-economic implications of the coronavirus pandemic (COVID-19): a review. Int J Surg. 2020:78:185-93.

7. Amzat J, Aminu K, Kolo VI, Akinyele AA, Ogundairo JA, Danjibo CM. Coronavirus outbreak in Nigeria: burden and socio-medical response during the first 100 days. Int J Infect Dis. 2020;98:1-16.

8. Talevi A, Bellera CL. Expert opinion on drug discovery challenges and opportunities with drug repurposing: finding strategies to find alternative uses of therapeutics. Expert Opin Drug Discov. 2020;15:397-401.

9. Jourdan J. Drug repositioning: a brief overview. J Pharm Pharmacol. 2020. https://doi.org/10.1111/jphp.13273.

10. Peyclit L, Baron SA, Yousfi H, Rolain J, Peyclit L, Baron SA, et al. Zidovudine: a salvage therapy for mcr-1 plasmid-mediated colistin-resistant bacterial infections? To cite this version: HAL Id: hal-01858892. Int J Antimicrob Agents. 2019;52:11-3.

11. Soo V, Quezada H, Perez B, Martinez-vazquez M. Repurposing of anticancer drugs for the treatment of bacterial infections. Curr Top Med Chem. 2017;17:1157-76

12. Meo SA, Klonoff DC, Akram J. Efficacy of chloroquine and hydroxychloroquine in the treatment of COVID-19. Eur Rev Med Pharmacol Sci. 2020:24:4539-47.

13. Gautret P, Lagier J-C, Parola P, Hoang VT, Meddeb L, Mailhe M, et al. Hydroxychloroquine and azithromycin as a treatment of COVID-19: results of an open-label non-randomized clinical trial. Int J Antimicrob Agents. 2020;56:105949.

14. Grein J, Ohmagari N, Shin D, Diaz G, Asperges E, Castagna A, et al. Compassionate use of remdesivir for patients with severe Covid-19. N Engl J Med. 2020. https://doi.org/10.1056/NEJMoa2007016.

15. Zhou Q, Chen V, Shannon CP, Wei X-S, Xiang X, Wang X, et al. Interferona2b treatment for COVID-19. Front Immunol. 2020;11:1061. https://doi. org/10.3389/fimmu.2020.01061.

16. Lansbury L, Lim B, Baskaran V, Lim WS. Co-infections in people with COVID-19: a systematic review and meta-analysis. J Infect. 2020:81:266-75.

17. Zhu X, Ge Y, Wu T, Zhao K, Chen Y, Wu B, et al. Co-infection with respiratory pathogens among COVID-2019 cases. Virus Res. 2020;285:198005.

18. Wu Q, Xing Y, Shi L, Li W, Gao Y, Pan S, et al. Coinfection and other clinical characteristics of COVID-19 in children. Pediatrics. 2020;146:e20200961.

19. Bahal N, Nahata MC. The new macrolide antibiotics: azithromycin, clarithromycin, dirithromycin, and roxithromycin. Ann Pharmacother. 1992;26:46-55

20. Madrid PB, Panchal RG, Warren TK, Shurtleff AC, Endsley AN, Green CE, et al. Evaluation of ebola virus inhibitors for drug repurposing. ACS Infect Dis. 2015;1:317-26.

21. Li C, Zu S, Deng Y-Q, Li D, Parvatiyar K, Quanquin N, et al. Azithromycin protects against Zika virus Infection by upregulating virus-induced type I and III interferon responses. Antimicrob Agents Chemother. 2019. https:// doi.org/10.1128/AAC.00394-19.

22. lannetta M, Ippolito G, Nicastri E. Azithromycin shows anti-Zika virus activity in human glial cells. Antimicrob Agents Chemother. 2017;61(9):e01152. https://doi.org/10.1128/AAC.01152-17.

23. Arikata M, Itoh $Y$, Shichinohe $S$, Nakayama M, Ishigaki H, Kinoshita T, et al. Efficacy of clarithromycin against H5N1 and H7N9 avian influenza a virus infection in cynomolgus monkeys. Antiviral Res. 2019;171:104591.

24. Takahashi E, Indalao IL, Sawabuchi T, Mizuno K, Sakai S, Kimoto T, et al. Clarithromycin suppresses induction of monocyte chemoattractant 
protein-1 and matrix metalloproteinase- 9 and improves pathological changes in the lungs and heart of mice infected with influenza A virus. Comp Immunol Microbiol Infect Dis. 2018;56:6-13.

25. Girard AE, Girard D, English AR, Gootz TD, Cimochowski CR, Faiella JA, et al. Pharmacokinetic and in vivo studies with azithromycin (CP-62,993), a new macrolide with an extended half-life and excellent tissue distribution. Antimicrob Agents Chemother. 1987;31:1948-54.

26. Gautret P, Lagier J-C, Parola P, Hoang VT, Meddeb L, Sevestre J, et al. Clinical and microbiological effect of a combination of hydroxychloroquine and azithromycin in 80 COVID-19 patients with at least a six-day follow up: a pilot observational study. Travel Med Infect Dis. 2020;34:101663.

27. Javelot H, El-Hage W, Meyer G, Becker G, Michel B, Hingray C. COVID-19 and (hydroxy)chloroquine-azithromycin combination: should we take the risk for our patients? Br J Clin Pharmacol. 2020;86:1176-7.

28. Gbinigie K, Frie K. Should azithromycin be used to treat COVID-19? A rapid review. BJGP Open. 2020. https://doi.org/10.3399/bjgpopen20 X101094.

29. Ohe M, Shida H, Jodo S, Kusunoki Y, Seki M, Furuya K, et al. Macrolide treatment for COVID-19: will this be the way forward? Biosci Trends. 2020;14:159-60.

30. Million M, Lagier J-C, Gautret P, Colson P, Fournier P-E, Amrane S, et al. Early treatment of COVID-19 patients with hydroxychloroquine and azithromycin: a retrospective analysis of 1061 cases in Marseille, France. Travel Med Infect Dis. 2020:35:101738.

31. Schwartz RA, Suskind RM. Azithromycin and COVID-19 prompt early use at first signs of this infection in adults and children an approach worthy of consideration. Dermatol Ther. 2020;33:e13785.

32. Andreani J, Le Bideau M, Duflot I, Jardot P, Rolland C, Boxberger M, et al. In vitro testing of combined hydroxychloroquine and azithromycin on SARS-CoV-2 shows synergistic effect. Microb Pathog. 2020;145:104228.

33. Tyteca D, Van Der Smissen P, Mettlen M, Van Bambeke F, Tulkens PM, Mingeot-Leclercq M-P, et al. Azithromycin, a lysosomotropic antibiotic, has distinct effects on fluid-phase and receptor-mediated endocytosis, but does not impair phagocytosis in $\mathbf{7 7 4}$ macrophages. Exp Cell Res. 2002;281:86-100

34. Pani A, Lauriola M, Romandini A, Scaglione F. Macrolides and viral infections: focus on azithromycin in COVID-19 pathology. Int J Antimicrob Agents. 2020;56(2):106053

35. Lin S-J, Kuo M-L, Hsiao H-S, Lee P-T. Azithromycin modulates immune response of human monocyte-derived dendritic cells and CD4+T cells. Int Immunopharmacol. 2016;40:318-26.

36. Amsden GW. Erythromycin, clarithromycin, and azithromycin: are the differences real? Clin Ther. 1996;18:56-72.

37. Millán-Oñate J, Millan W, Mendoza LA, Sánchez CG, Fernandez-Suarez H, Bonilla-Aldana DK, et al. Successful recovery of COVID-19 pneumonia in a patient from Colombia after receiving chloroquine and clarithromycin. Ann Clin Microbiol Antimicrob. 2020;19:16.

38. Kahne D, Leimkuhler C, Lu W, Walsh C. Glycopeptide and lipoglycopeptide antibiotics. Chem Rev Am Chem Soc. 2005:105:425-48.

39. Zhou N, Pan T, Zhang J, Li Q, Zhang X, Bai C, et al. Glycopeptide antibiotics potently inhibit cathepsin $\mathrm{L}$ in the late endosome/lysosome and block the entry of ebola virus, middle east respiratory syndrome coronavirus (MERS-CoV), and severe acute respiratory syndrome coronavirus (SARSCoV). J Biol Chem. 2016;291:9218-32.

40. Wang Y, Cui R, Li G, Gao Q, Yuan S, Altmeyer R, et al. Teicoplanin inhibits ebola pseudovirus infection in cell culture. Antiviral Res. 2016;125:1-7.

41. Baron SA, Devaux C, Colson P, Raoult D, Rolain J-M. Teicoplanin: an alternative drug for the treatment of COVID-19? Int J Antimicrob Agents, 2020;55:105944

42. Ceccarelli G, Alessandri F, d'Ettorre G, Borrazzo C, Spagnolello O, Oliva A, et al. Is teicoplanin a complementary treatment option for COVID-19? The question remains. Int J Antimicrob Agents. 2020:56:106029.

43. Zhang J, Ma X, Yu F, Liu J, Zou F, Pan T, et al. Teicoplanin potently blocks the cell entry of 2019-nCoV. bioRxiv. 2020. https://doi.org/10.1101/2020 02.05.935387.

44. Chopra I, Roberts M. Tetracycline antibiotics: mode of action, applications, molecular biology, and epidemiology of bacterial resistance. Microbiol Mol Biol Rev Am Soc Microbiol. 2001:65:232-60.

45. Rothan HA, Mohamed Z, Paydar M, Rahman NA, Yusof R. Inhibitory effect of doxycycline against dengue virus replication in vitro. Arch Virol. 2014:159:711-8.
46. Rothan HA, Buckle MJ, Ammar YA, Mohammadjavad P, Shatrah O, Noorsaadah AR, et al. Study the antiviral activity of some derivatives of tetracycline and non-steroid anti inflammatory drugs towards dengue virus. Trop Biomed. 2013;30:681-90.

47. Sturtz FG. Antimurine retroviral effect of doxycycline. Methods Find Exp Clin Pharmacol. 1998;20:643.

48. Skulason S, Holbrook WP, Thormar H, Gunnarsson GB, Kristmundsdottir T. A study of the clinical activity of a gel combining monocaprin and doxycycline: a novel treatment for herpes labialis. J Oral Pathol Med Off Publ Int Assoc Oral Pathol Am Acad Oral Pathol. 2012;41:61-7.

49. Wu Z, Wang X, Wei J, Li B, Shao D, Li Y, et al. Antiviral activity of doxycycline against vesicular stomatitis virus in vitro. FEMS Microbiol Lett. 2015;362(22):fnv195.

50. Bick MJ, Carroll J-WN, Gao G, Goff SP, Rice CM, MacDonald MR. Expression of the zinc-finger antiviral protein inhibits alphavirus replication. J Virol Am Soc Microbiol J. 2003;77:11555-62.

51. Tang $Q$, Wang $X$, Gao $G$. The short form of the zinc finger antiviral protein inhibits influenza a virus protein expression and is antagonized by the virus-encoded NS1. J Virol. 2017;91(2):e01909-16.

52. Sargiacomo C, Sotgia F, Lisanti MP. COVID-19 and chronological aging: senolytics and other anti-aging drugs for the treatment or prevention of corona virus infection? Aging. 2020;12:6511-7.

53. Fredeking TM, Zavala-Castro JE, González-Martínez P, Moguel-Rodríguez W, Sanchez EC, Foster MJ, et al. Dengue patients treated with doxycycline showed lower mortality associated to a reduction in IL-6 and TNF levels. Recent Patents Anti-Infect Drug Disc. 2015;10:51-8.

54. Mehta P, McAuley DF, Brown M, Sanchez E, Tattersall RS, Manson JJ, et al. COVID-19: consider cytokine storm syndromes and immunosuppression. Lancet Lond Engl. 2020;395:1033-4.

55. Quartuccio L, Semerano L, Benucci M, Boissier M-C, De Vita S. Urgent avenues in the treatment of COVID-19: targeting downstream inflammation to prevent catastrophic syndrome. Joint Bone Spine. 2020;87:191-3.

56. Wu C, Liu Y, Yang Y, Zhang P, Zhong W, Wang Y, et al. Analysis of therapeutic targets for SARS-CoV-2 and discovery of potential drugs by computational methods. Acta Pharm Sin B. 2020;10:766-88.

57. Clercq ED. Potential antivirals and antiviral strategies against SARS coronavirus infections. Expert Rev Anti Infect Ther (Taylor and Francis). 2006:4:291-302.

58. Wang J. Fast identification of possible drug treatment of coronavirus disease-19 (COVID-19) through computational drug repurposing study. J Chem Inf Model. 2020;60:3277-86.

59. Ezelarab HAA, Abbas SH, Hassan HA, Abuo-Rahma GE-DA. Recent updates of fluoroquinolones as antibacterial agents. Arch Pharm (Weinheim). 2018;351:e1800141.

60. Dalhoff A. Antiviral, antifungal, and antiparasitic activities of fluoroquinolones optimized for treatment of bacterial infections: a puzzling paradox or a logical consequence of their mode of action? Eur J Clin Microbiol Infect Dis Off Publ Eur Soc Clin Microbiol. 2015;34:661-8.

61. Ikeda S, Yazawa M, Nishimura C. Antiviral activity and inhibition of topoisomerase by ofloxacin, a new quinolone derivative. Antiviral Res. 1987:8:103-13

62. Richter S, Parolin C, Palumbo M, Palù G. Antiviral properties of quinolonebased drugs. Curr Drug Targets Infect Disord. 2004;4:111-6.

63. Witvrouw M, Daelemans D, Pannecouque C, Neyts J, Andrei G, Snoeck $R$, et al. Broad-spectrum antiviral activity and mechanism of antiviral action of the fluoroquinolone derivative K-12. Antivir Chem Chemother. 1998:9:403-11.

64. Karampela I, Dalamaga M. Could respiratory fluoroquinolones, levofloxacin and moxifloxacin, prove to be beneficial as an adjunct treatment in COVID-19? Arch Med Res. 2020;51(7):741-2.

65. Marciniec K, Beberok A, Boryczka S, Wrześniok D. Ciprofloxacin and moxifloxacin could interact with SARS-CoV-2 protease: preliminary in silico analysis. Pharmacol Rep. 2020;72(6):1553-61.

66. Metlay JP, Waterer GW. Treatment of community-acquired pneumonia during the coronavirus disease (COVID-19) pandemic. Ann Intern Med. 2020. https://doi.org/10.7326/M20-2189.

67. Dalhoff A, Shalit I. Immunomodulatory effects of quinolones. Lancet Infect Dis. 2003;3:359-71.

68. Riesbeck K. Immunomodulating activity of quinolones: review. J Chemother Florence Italy. 2002;14:3-12 
69. Serio AW, Magalhaes ML, Blanchard JS, Connolly LE. Aminoglycosides: mechanisms of action and resistance. In: Mayers D, Sobel J, Ouellette M, Kaye K, Marchaim D, editors. Antimicrobial drug resistance. Cham: Springer; 2017. https://doi.org/10.1007/978-3-319-46718-4_14.

70. Krause KM, Serio AW, Kane TR, Connolly LE. Aminoglycosides: an overview. Cold Spring Harb Perspect Med. 2016;6(6):a027029.

71. Woods Acevedo MA, Erickson AK, Pfeiffer JK. The antibiotic neomycin enhances coxsackievirus plaque formation. mSphere. 2019:4(1):e00632-18.

72. Gopinath S, Kim MV, Rakib T, Wong PW, van Zandt M, Barry NA, et al. Topical application of aminoglycoside antibiotics enhances host resistance to viral infections in a microbiota-independent manner. Nat Microbiol. 2018;3:611-21.

73. Chalichem NSS, Bethapudi B, Mundkinajeddu D. Aminoglycosides can be a better choice over macrolides in COVID-19 regimen: plausible mechanism for repurposing strategy. Med Hypotheses. 2020;144:109984.

74. Khurshid Z, Zafar MS, Naseem M, Khan RS, Najeeb S. Human oral defensins antimicrobial peptides: a future promising antimicrobial drug Curr Pharm Des. 2018;24:1130-7.

75. Holly MK, Diaz K, Smith JG. Defensins in viral infection and pathogenesis. Annu Rev Virol. 2017:4:369-91.

76. Park MS, Kim JI, Lee I, Park S, Bae J-Y, Park M-S. Towards the application of human defensins as antivirals. Biomol Ther. 2018;26:242-54.

77. Venkataraman N, Cole AL, Ruchala P, Waring AJ, Lehrer RI, Stuchlik O, et al. Reawakening retrocyclins: ancestral human defensins active against HIV1. PLoS Biol. 2009;7:e95.

78. Wilson SS, Wiens ME, Smith JG. Antiviral mechanisms of human defensins. J Mol Biol. 2013:425:4965-80.

79. Izquierdo-Dominguez A, Rojas-Lechuga MJ, Mullol J, Alobid I. Olfactory dysfunction in the COVID-19 outbreak. J Investig Allergol Clin Immunol. 2020;30(5):317-26.

80. Thiem U, Heppner H-J, Pientka L. Elderly patients with communityacquired pneumonia: optimal treatment strategies. Drugs Aging. 2011;28:519-37

81. Durojaiye AB, Clarke J-RD, Stamatiades GA, Wang C. Repurposing cefuroxime for treatment of COVID-19: a scoping review of in silico studies. J
Biomol Struct Dyn. 2020. https://doi.org/10.1080/07391102.2020.17779 04.

82. Pani A, Lauriola M, Romandini A, Scaglione F. Macrolides and viral infections: focus on azithromycin in COVID-19 pathology. Int J Antimicrob Agents. 2020;56:106053.

83. Choudhary R, Sharma AK, Choudhary R. Potential use of hydroxychloroquine, ivermectin and azithromycin drugs in fighting COVID-19: trends, scope and relevance. N Microbes N Infect. 2020;35:100684.

84. Touret F, Gilles M, Barral K, Nougairède A, Decroly E, de Lamballerie X, et al. In vitro screening of a FDA approved chemical library reveals potential inhibitors of SARS-CoV-2 replication. bioRxiv (Cold Spring Harbor Laboratory). 2020;48:92

85. Sathyamoorthy N, Chintamaneni PK, Chinni S. Plausible role of combination of chlorpromazine hydrochloride and teicoplanin against COVID-19. Med Hypotheses. 2020;144:110011.

86. He B, Garmire L. Prediction of repurposed drugs for treating lung injury in COVID-19. ArXiv. 2020;9:609.

87. Sodhi M, Etminan M. Therapeutic potential for tetracyclines in the treatment of COVID-19. Pharmacotherapy (Hoboken: Wiley). 2020;40:487-8.

88. Conforti C, Giuffrida R, Zalaudek I, Di Meo N. Doxycycline, a widely used antibiotic in dermatology with a possible anti-inflammatory action against IL-6 in COVID-19 outbreak. Dermatol Ther. 2020;33:e13437.

89. Farouk A, Salman S. Dapsone and doxycycline could be potential treatment modalities for COVID-19. Med Hypotheses. 2020;140:109768.

90. Malek AE, Granwehr BP, Kontoyiannis DP. Doxycycline as a potential partner of COVID-19 therapies. IDCases. 2020;21:e00864.

91. Szolnoky G. Further aspects of doxycycline therapy in COVID-19. Dermatol Ther. 2020; https://doi.org/10.1111/dth.13810.

92. Bonzano C, Borroni D, Lancia A, Bonzano E. Doxycycline: from ocular rosacea to COVID-19 anosmia. New insight into the coronavirus outbreak. Front Med. 2020;7:200.

\section{Publisher's Note}

Springer Nature remains neutral with regard to jurisdictional claims in published maps and institutional affiliations.
Ready to submit your research? Choose BMC and benefit from:

- fast, convenient online submission

- thorough peer review by experienced researchers in your field

- rapid publication on acceptance

- support for research data, including large and complex data types

- gold Open Access which fosters wider collaboration and increased citations

- maximum visibility for your research: over $100 \mathrm{M}$ website views per year

At BMC, research is always in progress.

Learn more biomedcentral.com/submissions 